\title{
Genetic types and distribution of shallow-buried natural gases
}

\author{
Gao Yang ${ }^{1}$, Jin Qiang ${ }^{1 *}$ and Zhu Guangyou ${ }^{2}$ \\ ${ }^{1}$ College of Geo-resources and Information, China University of Petroleum, Dongying, Shandong 257061, China \\ ${ }^{2}$ Petroleum Exploration and Development Institute, PetroChina, Beijing 100083, China \\ (C) China University of Petroleum (Beijing) and Springer-Verlag Berlin Heidelberg 2010
}

\begin{abstract}
Great volumes of shallow-buried $(<2,000 \mathrm{~m})$ natural gases which are mainly composed of biogases and low-mature gases have been found in the Mesozoic-Cenozoic sedimentary basins in China. Many shallow gas reservoirs in China are characterized by coexistence of biogas and low-mature gas, so identifying the genetic types of shallow gases is important for exploration and development in sedimentary basins. In this paper, we study the gas geochemistry characteristics and distribution in different basins, and classify the shallow gas into two genetic types, biogas and low-mature gas. The biogases are subdivided further into two subtypes by their sources, the source rock-derived biogas and hydrocarbon-derived biogas. Based on the burial history of the source rocks, the source rock-derived biogases are divided into primary and secondary biogas. The former is generated from the source rocks in the primary burial stage, and the latter is from uplifted source rocks or those in a secondary burial stage. In addition, the identifying parameters of each type of shallow gas are given. Based on the analysis above, the distributions of each type of shallow gas are studied. The primary biogases generated from source rocks are mostly distributed in Quaternary basins or modern deltas. Most of them migrate in watersoluble or diffused mode, and their migration distance is short. Reservoir and caprock assemblages play an important role in primary biogas accumulation. The secondary biogases are distributed in a basin with secondary burial history. The oil-degraded biogases are distributed near heavy oil pools. The low-mature gases are widely distributed in shallow-buried reservoirs in the Meso-Cenozoic basins.
\end{abstract}

Key words: Primary biogas, secondary biogas, oil-degraded biogas, low-mature gas, genetic type, gas identification, gas accumulation, distribution

\section{Introduction}

In oil and gas exploration, the natural gas which occurs at depths of less than 2,000 meters is often known as shallow gas. It is widely distributed in the Meso-Cenozoic basins in China, such as the Qaidam, Junggar, Songliao, and Bohai Bay basins, and is mainly composed of biogas and low-mature gas. The biogas is also distributed in the sediments of deltas, such as the Yangtze River Delta. By the end of 2006, the proven geological reserves of biogas are estimated to be $2,860 \times 10^{8}$ $\mathrm{m}^{3}$, and the total geological reserves are estimated to be $38,629 \times 10^{8} \mathrm{~m}^{3}$, which means that the proven reserves account for only $7.4 \%$ of the estimated biogas resource (Zhang et al, 2005).

Rice and Claypool (1981) proposed that biogas was generated from organic matter in shallow-buried deposits in a reducing environment. They stated that it is rich in methane and there are two ways for biogas generation, acetic acid fermentation and $\mathrm{CO}_{2}$ reduction. Pallasser (2000) found that

*Corresponding author. email: jinqiang@upc.edu.cn

Received January 7, 2009 biogas can be generated from trapped oil by biodegradation. Moreover, the organic matter in shallow-buried sediments can also generate gas rich in methane before thermal degradation (Xu et al, 1990; Xu, 1994; Wang et al, 1988; 2003b). This is called low-mature gas. The biogases are formed by anaerobic bacteria, while the low-mature gases are generated in low temperature and low maturity conditions (Song and $\mathrm{Xu}$, 2005).

Many shallow gas reservoirs in China are characterized by coexistence of biogas and low-mature gas with different genetic types. Examples include the gas reservoirs in the Liuquan structure of the Langgu Sag and in the Jinhu Sag, northern Jiangsu. Because different genetic types of shallow-buried gases have different accumulation processes, identifying the genetic types is significant for understanding the gas accumulation.

Based on the geochemical characteristics of shallowburied gases in different basins, we define the genetic types of gases according to their source materials and develop an identification standard. The accumulation and distribution of the shallow gases is discussed with examples, which helps exploration for shallow gases in different basins. 


\section{Genetic types of shallow-buried gases}

There is not a uniform classification for biogases and lowmature gases. In foreign countries, little attention is focused on the genetic types of shallow-buried gases and research has concentrated mainly on coalbed methane (CBM). Based on the study of coal bed biogenic methane in the Powder River Basin, Flores et al (2008) suggested that biogases could be divided into $\mathrm{CO}_{2}$ reduction biogas and acetic acid fermentation biogas. In China, Dai (1992) believed that the shallow-buried gases consisted of biogases and sub-biogases. $\mathrm{Xu}$ (1994) suggested that the shallow-buried gases had two types, biogases and bio-thermal-catalytic transitional gases. $\mathrm{Li}$ et al (2005a) divided the biogases into primary biogases and secondary biogases.

Based on the study in the Qaidam, Bohai Bay, Turpan-
Hami, and Yinggehai-Qiongnan basins, the shallow-buried gases are divided into biogases and low-mature gases, and then the biogases are subdivided into two types according to their sources, one is from source rocks, and the other is from hydrocarbon reservoirs. The biogases derived from source rocks are further classified into primary biogases and secondary biogases. Table 1 gives the identifying parameters for each type of the gases.

\subsection{Primary biogas}

The methane content of primary biogases is as high as $98 \%$, the ethane and higher alkane $\left(\mathrm{C}_{2+}\right)$ content is very low (about $0.5 \%$ ), the $\mathrm{C}_{1} / \mathrm{C}_{1-5}$ ratio is greater than 0.99 , and the nonhydrocarbon contents are less than 5\% (Table 2). The $\delta^{13} \mathrm{C}_{1}$ of the primary biogas is less than $-55 \%$ (Rice and Claypool, 1981; Dai, 1992).

Table 1 Genetic types and identifying parameters of biogases and low-mature gases

\begin{tabular}{|c|c|c|c|c|}
\hline \multirow{3}{*}{ Genetic types } & \multicolumn{3}{|c|}{ Biogas } & \multirow{3}{*}{ Low-mature gas } \\
\hline & \multicolumn{2}{|c|}{ Derived from source rocks } & \multirow{2}{*}{\begin{tabular}{|c|}
$\begin{array}{c}\text { Derived from hydrocarbon } \\
\text { reservoirs }\end{array}$ \\
Oil-degraded biogas
\end{tabular}} & \\
\hline & Primary biogas & Secondary biogas & & \\
\hline Generation process & $\begin{array}{c}\text { Generated from immature } \\
\text { source rocks in primary } \\
\text { burial history }\end{array}$ & $\begin{array}{c}\text { Generated from source rocks } \\
\text { in uplift or secondary burial } \\
\text { history }\end{array}$ & Oil biodegradation & $\begin{array}{c}\text { Thermal degradation from } \\
\text { source rocks in the low } \\
\text { maturity stage }\end{array}$ \\
\hline Gas composition & Mainly methane, little $\mathrm{C}_{2+}$ & $\begin{array}{l}\text { Mainly methane, a little } \mathrm{C}_{2+}, \\
\qquad \mathrm{CO}_{2} \text { and } \mathrm{N}_{2}\end{array}$ & $\begin{array}{l}\text { Mainly methane, little } \mathrm{C}_{2+} \text {, } \\
\text { more } \mathrm{N}_{2} \text { than other biogas }\end{array}$ & $\begin{array}{c}\mathrm{C}_{1} / \mathrm{C}_{1-5} \text { between } 0.7 \text { and } 0.89, \\
\text { a little nonhydrocarbon }\end{array}$ \\
\hline Carbon isotope composition & $\delta^{13} \mathrm{C}_{1}<-55 \% 0, \delta^{13} \mathrm{C}_{2}<-40 \%$ & $\delta^{13} \mathrm{C}_{1} \leq-50 \%, \delta^{13} \mathrm{C}_{2}>-40 \%$ & $-50 \%{ }_{0}<\delta^{13} \mathrm{C}_{1}<-75 \%$ & $-45 \% 0<\delta^{13} \mathrm{C}_{1}<-55 \%$ \\
\hline Examples & $\begin{array}{c}\text { Qaidam, Yangtze River } \\
\text { Delta, Jiangsu Basin }\end{array}$ & Langgu Sag & $\begin{array}{c}\text { West slope of Songliao Basin, } \\
\text { Jiyang Depression }\end{array}$ & $\begin{array}{l}\text { Turpan-Hami Basin } \\
\text { Liaohe Depression }\end{array}$ \\
\hline
\end{tabular}

Primary biogases are generated by acetic acid fermentation or $\mathrm{CO}_{2}$ reduction. The latter is the main source of biogas. $\delta \mathrm{D}_{\mathrm{CH}_{4}}$ from acetic acid fermentation is less than $-300 \%$, and $\delta \mathrm{D}_{\mathrm{CH}_{4}}$ from $\mathrm{CO}_{2}$ reduction ranges between $-300 \%$ and $-160 \%$. Whiticar et al (1986) analyzed 500 natural gas samples from different basins all over the world and suggested that the $\delta \mathrm{D}_{\mathrm{CH}_{4}}$ value of natural gases derived from source rocks deposited in fresh-water environment is lower than that of natural gases derived from source rocks deposited in saline waters. Therefore, $\delta \mathrm{D}_{\mathrm{CH}_{4}}$ is not an effective indicator for biogas identification.

The primary biogases are distributed mainly in the Quaternary in the Qaidam Basin, Neocene-Quaternary in the Yinggehai-Qiongnan Basin, and the Yangtze River Delta. A few primary biogas reservoirs are found in the Tertiary.

\subsection{Secondary biogas}

Shi (2002) conducted biochemical experiments on source rocks sampled from the Mesozoic in the Liaohe Depression and from the Tertiary in the Langgu Sag, and demonstrated that the source rocks after thermal maturation could also generate biogas.

Secondary biogas is usually mixed with low-mature gas in a reservoir. The methane content in the secondary biogas is as high as $98 \%$, while the heavy hydrocarbon contents are less than $2 \%\left(\mathrm{C}_{1} / \mathrm{C}_{1-5}\right.$ ratio $\left.>0.98\right)$ and the nonhydrocarbon contents are rather low. Carbon isotope compositions of methane in the secondary biogases are slightly heavier than those in the primary biogases. Meanwhile, the carbon isotope compositions of ethane and propane in the secondary biogas are also heavier than those in the primary biogas (Table 3 ).

The sedimentary basins in east China experienced rifting in the Tertiary, and were uplifted in the Himalayan movement. Before the movement, the basins were in the primary burial stage and some source rocks were in the biogas generation stage. After the movement, some source rocks returned to the bacterial activity zone so that secondary biogas was generated. The secondary biogases are mainly distributed in the Bohai Bay Basin and small Tertiary basins, such as the Baoshan and Qujing basins in the Yunnan Province.

\subsection{Oil-degraded biogas}

Anaerobic microorganisms generate biogas from oils in shallow-buried reservoirs (Zhu et al, 2005). In oil biodegradation, the oil loses its light hydrocarbon components, so that its density, viscosity and sulfur content increase (Zhu et al, 2007).

Because of the isotope fractionation which occurs during the oil biodegradation, the carbon isotope value of methane in the oil-degraded biogas is very low $(-100 \% 0--55 \%)$, and 
Table 2 Geochemical characteristics of primary biogas in China

\begin{tabular}{|c|c|c|c|c|c|c|c|c|}
\hline \multirow{2}{*}{ Structural belt } & \multirow{2}{*}{ Well No. } & \multirow{2}{*}{ Strata } & \multirow{2}{*}{ Depth, m } & \multicolumn{3}{|c|}{ Gas composition, $\%$} & \multirow{2}{*}{$\delta^{13} \mathrm{C}_{1}, \%$} & \multirow{2}{*}{$\mathrm{C}_{1} / \mathrm{C}_{1+}$} \\
\hline & & & & $\mathrm{CH}_{4}$ & $\mathrm{C}_{2} \mathrm{H}_{6}$ & Nonhydrocarbon & & \\
\hline \multirow{6}{*}{ Yangxin Sub-sag } & Y1 & $\mathrm{Es}_{1}$ & 1504 & 98.1 & 0 & 1.91 & -- & 1 \\
\hline & Y101 & $\mathrm{Es}_{1}$ & 1504 & 98.4 & 0.17 & 1.04 & -60.6 & 0.9985 \\
\hline & Y15 & $\mathrm{Es}_{1}$ & 1412 & 97.0 & 0.08 & 1.79 & -60.9 & 0.9992 \\
\hline & Y16 & $\mathrm{Es}_{1}$ & 1309 & 97.8 & 0.18 & 2.06 & -56.5 & 0.9982 \\
\hline & Y21 & $\mathrm{Es}_{1}$ & 1520 & 95.0 & 0 & 5.00 & -- & 1 \\
\hline & & Average & & 97.3 & 0.14 & 2.36 & -59.3 & 0.9986 \\
\hline \multirow{6}{*}{ Qaidam Basin } & $\mathrm{TN}$ & $\mathrm{Q}_{1-2}$ & -- & 94.3 & 0 & 5.73 & -69.9 & 1 \\
\hline & SB1 & $\mathrm{Q}_{1-2}$ & -- & 98.7 & 0.13 & 1.15 & -66.8 & 0.9986 \\
\hline & SB2 & $\mathrm{Q}_{1-2}$ & -- & 98.4 & 0 & 1.6 & -65.4 & 1 \\
\hline & YH & $\mathrm{Q}_{1-2}$ & -- & 95.2 & 0.28 & 4.52 & -65.0 & 0.9971 \\
\hline & TFS & $\mathrm{Q}_{1-2}$ & -- & 99.9 & 0 & 0.15 & -68.8 & 1 \\
\hline & & Average & & 97.3 & 0.08 & 2.63 & -67.18 & 0.9992 \\
\hline \multirow{6}{*}{ Southeast Littoral } & $\mathrm{J} 1$ & Q & -- & 96.2 & -- & 3.12 & -74.2 & -- \\
\hline & L1 & Q & -- & 94.2 & -- & 2.08 & -- & -- \\
\hline & D1 & Q & -- & 92.3 & -- & 2.03 & -- & -- \\
\hline & $\mathrm{T} 1$ & Q & -- & 93.9 & -- & 2.04 & -- & -- \\
\hline & F6 & Q & -- & 91.4 & -- & 1.47 & -84.5 & -- \\
\hline & & Average & & 93.6 & -- & 2.15 & -79.4 & -- \\
\hline
\end{tabular}

Table 3 Geochemical characteristics of $\mathrm{Es}_{3}$ biogas reservoir in the Liuquan structure

\begin{tabular}{|c|c|c|c|c|c|c|c|c|}
\hline \multirow{2}{*}{ Well No. } & \multirow{2}{*}{ Strata } & \multirow{2}{*}{ Depth, m } & \multicolumn{4}{|c|}{ Gas composition, $\%$} & \multirow{2}{*}{$\delta^{13} \mathrm{C}_{1}, \%$} & \multirow{2}{*}{$\mathrm{C}_{1} / \mathrm{C}_{1+}$} \\
\hline & & & $\mathrm{CH}_{4}$ & $\mathrm{C}_{2} \mathrm{H}_{6}$ & $\mathrm{~N}_{2}$ & $\mathrm{CO}_{2}$ & & \\
\hline G26 & $\mathrm{Es}_{3}$ & 1530 & 98.5 & 1.09 & 0.32 & 0.1 & -55.7 & 0.99 \\
\hline G131 & $\mathrm{Es}_{3}$ & 1168 & 98.6 & 0.05 & 1.36 & 0.05 & -57.2 & 0.99 \\
\hline G13 & $\mathrm{Es}_{3}$ & 1612 & 97.2 & 1.62 & 0.63 & 0.19 & -55.9 & 0.98 \\
\hline G131 & $\mathrm{Es}_{3}$ & 1597 & 96.8 & 2.11 & 0.81 & 0.12 & -54.3 & -- \\
\hline Q36 & $\mathrm{Es}_{3}$ & 1001 & 98.8 & 0.63 & 0.167 & 0.32 & -51.1 & 0.99 \\
\hline \multirow[t]{2}{*}{ XQ2 } & $\mathrm{Es}_{3}$ & 1135 & 99.0 & 0 & 1.17 & -- & -55.6 & 0.99 \\
\hline & Average & & 98.2 & 0.91 & 0.74 & 0.15 & -55.0 & 0.988 \\
\hline
\end{tabular}

$\delta^{13} \mathrm{C}$ of $\mathrm{CO}_{2}$ is abnormally high (up to $+2 \%$ ) (Table 4). Oildegraded biogases are often distributed with heavy oils, and usually accumulate with other shallow-buried gases.

The oil-degraded biogases have been found in the west slope of the Songliao Basin, Bohai Bay and Junggar basins. The potential reserves of oil-degraded biogases in the Songliao Basin are estimated to be about $240 \times 10^{8} \mathrm{~m}^{3}$.

\subsection{Low-mature gas}

The low-mature gas is also called early thermal genetic gas or bio-thermal-catalytic transitional gas (Xu et al, 1990). Actually, it is formed after the biogas generation and before the oil generation peak (Xu, 1994; 1999).

Low-mature gases are characterized by lower $\mathrm{C}_{1} / \mathrm{C}_{1-5}$ ratio (0.7-0.9) and heavier carbon isotope $\left(\delta^{13} \mathrm{C}_{1}\right.$ between $-55 \%$ and $-42 \%$ ) compared with those of biogases.

The identification of low-mature gas is a disputed issue. Galimov (1988) believed that $R_{0}$ of the source rocks generating low-mature gas ranged from $0.5 \%$ to $0.7 \%$ based on the study of Siberian gas. Wang et al (2003b) concluded that the low-mature gases are generated from the source rocks with $R_{\mathrm{o}}$ from $0.4 \%$ to $0.55 \%$, even up to $0.7 \%$, and the burial depth of the source rocks is $1,000-2,500 \mathrm{~m}$, even up to 3,000 $\mathrm{m}$. Xu et al (2008) suggested that source rocks generated low- 
Table 4 Geochemical characteristics of oil-degraded biogas in the Songliao Basin

\begin{tabular}{|c|c|c|c|c|c|c|c|c|}
\hline \multirow{2}{*}{ Well } & \multicolumn{4}{|c|}{ Gas composition, $\%$} & \multirow{2}{*}{$\mathrm{C}_{1} / \mathrm{C}_{1+}$} & \multirow{2}{*}{$\delta^{13} \mathrm{C}_{1}, \%$} & \multirow{2}{*}{$\delta^{13} \mathrm{C}_{2}, \%$} & \multirow{2}{*}{$\delta^{13} \mathrm{C}_{\mathrm{CO}_{2}}, \%$} \\
\hline & $\mathrm{CH}_{4}$ & $\mathrm{C}_{2+}$ & $\mathrm{CO}_{2}$ & $\mathrm{~N}_{2}$ & & & & \\
\hline D2-2 & 94.4 & 0.08 & 0.059 & 5.405 & 0.9992 & -56.32 & -44.2 & -2.69 \\
\hline D5-3 & 93.93 & 0.06 & 0.062 & 5.898 & 0.9994 & -57.55 & -46.2 & 0.82 \\
\hline D6 & 90.63 & 0.03 & 0.099 & 9.162 & 0.9997 & -59.06 & -46.7 & -1.89 \\
\hline D602 & 91.14 & 0.05 & 0.072 & 8.665 & 0.9995 & -58.93 & -47.6 & 0.95 \\
\hline D603 & 91.66 & 0.12 & 0.115 & 8.031 & 0.9987 & -58.45 & -51.3 & -3.87 \\
\hline D610 & 91.26 & 0.06 & 0.087 & 8.511 & 0.9993 & -58.75 & -47.4 & -6.9 \\
\hline D621 & 89.86 & 0.13 & 0.091 & 9.328 & 0.9986 & -59.45 & -47.3 & -18.78 \\
\hline D2-2 & 94.4 & 0.078 & 0.059 & 5.405 & 0.9992 & -56.32 & -44.2 & -2.69 \\
\hline D5-3 & 93.93 & 0.058 & 0.062 & 5.898 & 0.9994 & -57.55 & -46.2 & 0.82 \\
\hline D610 & 91.26 & 0.059 & 0.087 & 8.511 & 0.9994 & -58.75 & -47.4 & -6.9 \\
\hline D602 & 91.14 & 0.051 & 0.072 & 8.665 & 0.9996 & -58.93 & -47.6 & 0.95 \\
\hline D6 & 90.63 & 0.032 & 0.099 & 9.162 & 0.9986 & -59.06 & -46.7 & -1.89 \\
\hline D603 & 91.66 & 0.115 & 0.115 & 8.031 & 0.9987 & -58.45 & -51.3 & -3.87 \\
\hline
\end{tabular}

mature gas when $R_{\mathrm{o}}$ was less than $0.8 \%$.

\section{Distribution of various genetic types of shallow-buried gases}

The distributions of shallow-buried gases are controlled by the sources. Biogas generation needs conditions suitable for microorganism metabolism, such as temperature between $35^{\circ} \mathrm{C}$ and $75^{\circ} \mathrm{C}$ and appropriate $\mathrm{pH}$, Eh and salinity (Chen et al, 1994). The distribution of shallow-buried gases is also controlled by structural aspects, sedimentary facies and seal qualities.

\subsection{Distribution of primary biogases}

The primary biogases are mainly distributed in the Quaternary basins or modern delta deposits, such as the eastern Qaidam Basin and the Yangtze River Delta. The primary biogases migrate in water-soluble or diffused mode. The migration distance is short, so most of the biogas reservoirs are distributed near the source kitchens.

The primary biogas reservoirs have high porosity and permeability due to their weak diagenesis. The dynamic balance of charging and dissipating of biogases in the reservoirs plays an important role in the biogas accumulation. In general, the biogas charging quantity is closely controlled by gas generating intensity. If the biogas source is sufficient, the cap-rock controls the enrichment of biogas in the charging area.

Taking the $\mathrm{Es}_{1}$ primary biogas reservoir in the Yangxin Sub-sag for example, a series of traps are developed on the slope and structural highs, just updip on the source kitchen, and are charged fully with the biogas (Fig. 1). Its source rocks are grey mudstones and dark-grey oil shales with $R_{\mathrm{o}}$ between $0.27 \%$ and $0.35 \%$, and TOC contents between $0.22 \%$ and
$11.80 \%$. The source rocks have been in the biogas generation stage since $\mathrm{Ng}$. The reservoirs are mainly bioclastic limestones and dolomites deposited in lakeshore or sand sheet facies with high porosity and permeability with a caprock of lacustrine mudstones.

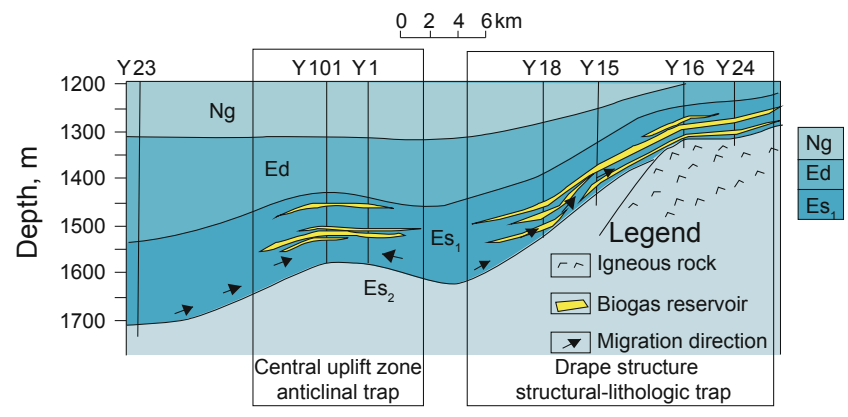

Fig. $1 \mathrm{Es}_{1}$ primary biogas accumulation in the Yangxin Sub-sag

The biogases in the Yangxin Sub-sag migrated in watersoluble or diffused mode. The migration distance is short because the biogases diffuse easily in rocks with weak diagenesis. Biogases mostly accumulated in the central uplift near the sub-sags. In the central uplift, many traps developed, which were suitable for gas capturing (Fig. 1). Biogases from the west sub-sag accumulated in the eastern drape structure and finally structural-lithologic gas pools were formed. The biogases in the Yangxin Sub-sag were preserved because of good cap-rocks and a lack of faulting.

\subsection{Distribution of secondary biogases}

Study of secondary biogas has been mainly about whether the source rocks are able to generate biogas after thermal evolution, but the distribution of secondary biogas is less 
studied.

The source rocks of the secondary biogas experienced thermal evolution, and were then uplifted to the bacterial activity zone. These source rocks are widely distributed in basins. During the Mesozoic-Tertiary, some basins were in a rifting stage and in deep-water environments, so that source rocks were deposited. In the Himalayan movement, most of the basins were uplifted, and the source rocks went back into the biological activity zone. Thus, the secondary biogases could be generated.

Faults are well developed in the rift basins. The faults not only provide good migration pathways for biogases when they are active, but also act as a good seal for the biogases when they are not active.

Taking the $\mathrm{Es}_{3}$ secondary biogas in the Liuquan structure as an example, fault activities are significant in gas accumulation (Fig. 2).

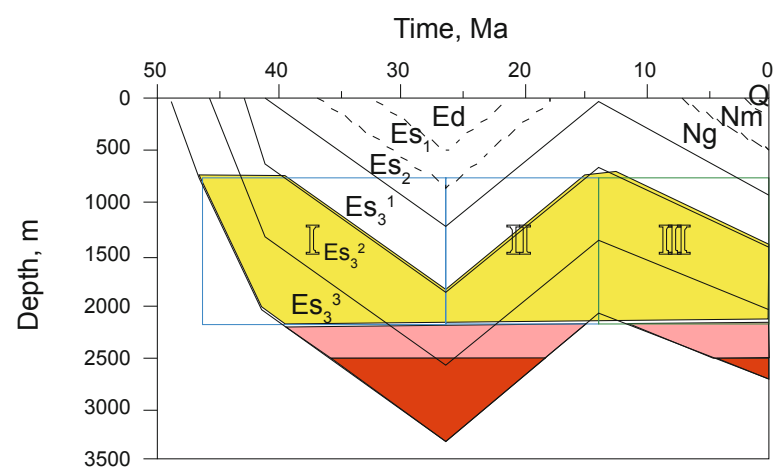

Fig. 2 Burial history of $\mathrm{Es}_{3}{ }^{3}$-Ed source rocks of the Q35 well

The source rocks of Liuquan biogases are mainly dark lacustrine mudstones with thicknesses of $1,100 \mathrm{~m}$. Their TOC contents are $1.24 \%-1.98 \%$, and $R_{\mathrm{o}}$ value is generally 0.5 . The kerogen type is mainly $\mathrm{II}_{1}-\mathrm{II}_{2}$. The source rocks are less than 2,000 $\mathrm{m}$ deep because of tectonic movements, and are favorable for biogas generation. The reservoirs consist of delta, fan delta and sublacustrine fan sandstones. The porosity is from $11.2 \%$ to $32.6 \%$ with an average of $26.8 \%$, and the permeability is $0.1-876 \mathrm{md}$ with an average of 193.6 $\mathrm{md}$. The lacustrine mudstones cover the reservoirs directly as caprocks.

The Liuquan structure has experienced complex tectonic activities, and many faults are developed. The distributions of biogases are controlled by the source conditions and fault activities. The evolution of source rocks can be divided into three stages, I: primary subsidence stage, II: uplift stage, III: secondary subsidence stage (Fig. 2).

During the first two stages, almost all faults are active, and the sediments are strongly uplifted by the structural movement so biogases were not easily preserved. Taking the Q2 well as an example, the distance between the top of the $\mathrm{Es}_{3}$ formation and the bottom of the $\mathrm{Ng}$ formation is only 100 m (Fig. 3). After Ng, the secondary biogases are easy to be preserved because of weak fault activities.

Therefore, secondary biogas accumulation occurs in basins or depressions with uplifting or secondary burial history, and is controlled by fault activities.

\subsection{Distribution of oil-degraded biogas}

Oil-degraded biogases accumulated near heavy oil pools. In the biogas generation, water activity is important for microorganism propagation so that the biogas reservoirs are often located near the oil-water contact. The biogas reserves are determined by the quantity of biodegraded oils.

Oil-degraded biogases are distributed in shallow reservoirs in the Songliao, Bohai Bay (Fig. 4) and Junggar basins, because many heavy oil reservoirs are distributed in these basins.

The Alaxin lithologic-structural gas reservoir is located in the west slope of the Songliao Basin. It is less than $700 \mathrm{~m}$ deep. The reserves of biogases are $1.74 \times 10^{9} \mathrm{~m}^{3}$, and the daily gas production is $0.115 \times 10^{6} \mathrm{~m}^{3}$. It is a shallow-buried, low abundance, high production small gas field. The gases are characterized by high methane content and relatively light $\delta^{13} \mathrm{C}_{1}$ with the content from $-83.88 \%$ to $-58.25 \%$, showing microorganism degradation characteristics.

The sources of Alaxin biogases are oil pools (reserves are 3.15 million ton) around the biogases. The oil pools are commonly degraded and most of the n-alkane in oil has been degraded by microorganisms(Fig. 5). The Alaxin biogas reservoirs are grey green mudstones and siltstones deposited

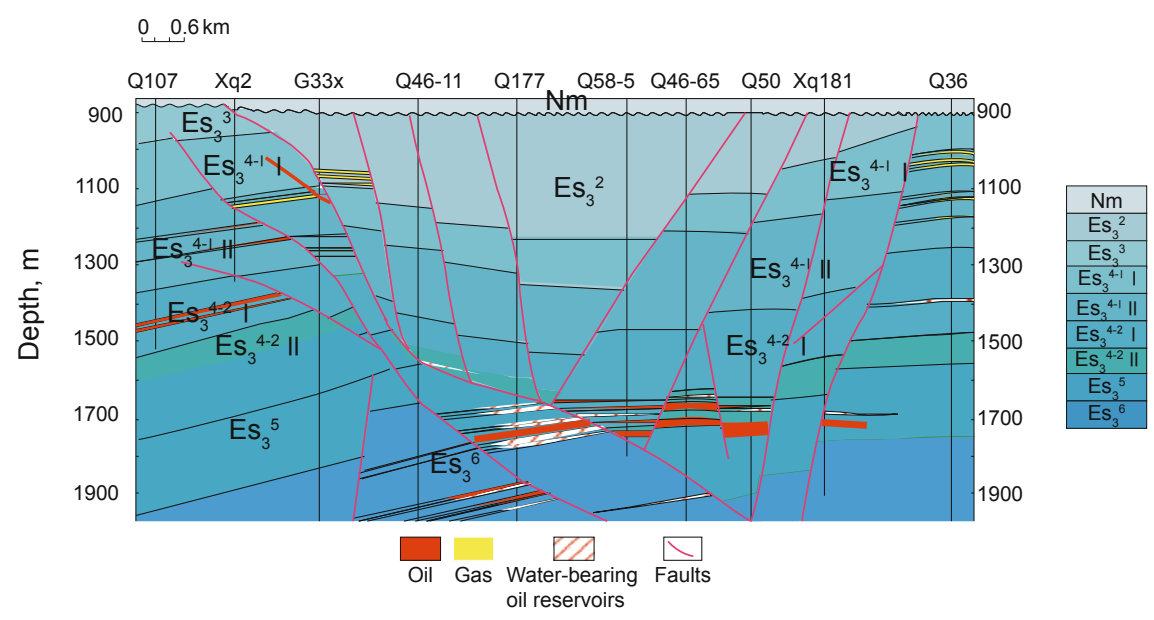

Fig. 3 Oil and gas accumulation in the Liuquan structure in the Langgu Sag 


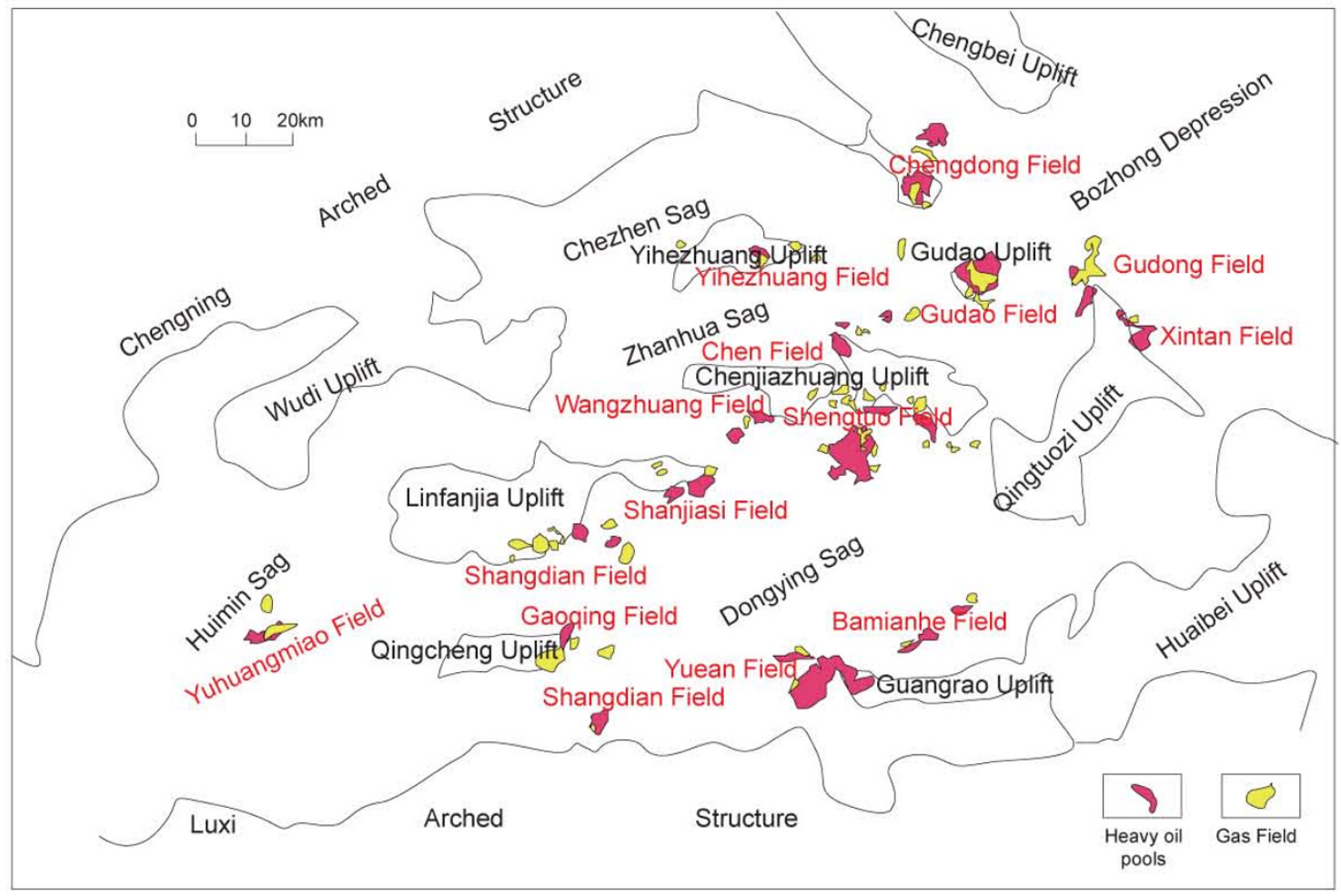

Fig. 4 Relationship between the distribution of heavy oil and shallow gas in the Bohai Bay Basin
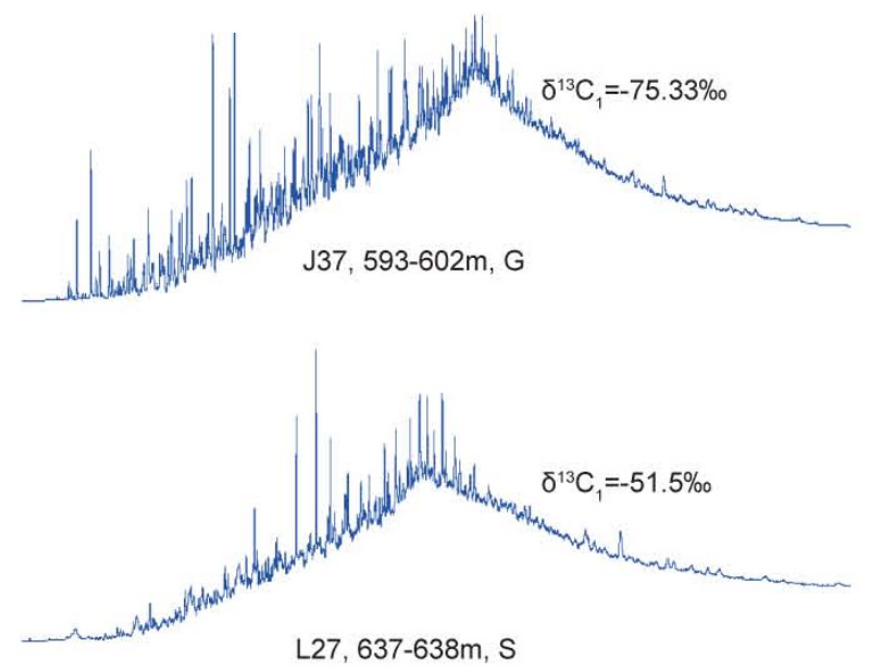

Fig. 5 Chromatogram of oil associated with biogas in the Alaxin oilfield

in the Saertu formation of beach bar facies. These reservoirs are thin in single layer with limited lateral distribution with mudstone cap rock.

The Alaxin structure was uplifted before the hydrocarbon generation stage of the Gulong Sub-sag. It is prior to the

\footnotetext{
${ }^{1}$ Yang Y F, et al. Oil-degraded biogas in the Songliao Basin. Biogas and low-mature gas generation and accumulation mechanism conference. 2006

${ }^{2}$ Peng P A, et al. Generated dynamics and genetic identification of lowmature gas. Biogas and low-mature gas generation and accumulation mechanism conference. 2008
}

capture of oil and gas. According to the research of Yang et $\mathrm{al}^{1}$, the hydrocarbon accumulation can be divided into three stages, $56 \mathrm{Ma}, 45 \mathrm{Ma}$, and $35 \mathrm{Ma}$, all after the oil and gas generation period of the Songliao Basin.

\subsection{Distribution of low-mature gas}

Xu et al (2008) proposed a $R_{0} 0.8 \%$ upper limit for the source rocks that generate low-mature gas. This gives a great scope for exploration for low-mature gases. According to their calculation, the low-mature gas resources in the Turpan-Hami Basin are more than $1 \times 10^{11} \mathrm{~m}^{3}$. During the low-maturity stage, there are varieties of catalysis in the gas generation process, such as biological catalysis and clay mineral catalysis (Liu and Xu, 1995; 1996). So maturity can not be used as the only indicator for the assessment of lowmature gas source rocks. At low temperature, the activation energy for low-mature gas generation of Mesozoic source rocks in the Turpan-Hami Basin is lower than that in other basins (Table 5). It is a special reason why low-mature gases are very rich in the Turpan-Hami Basin.

Low mature and immature source rocks are widely distributed in petroliferous basins. Peng et $\mathrm{al}^{2}$ concluded from pyrolysis experiments that the activation energy of gas generation in humic source rocks is lower than that of sapropelic source rocks, which showed that the humic source rocks are more likely to generate low-mature gas.

\section{Conclusions}

The shallow gas in the Qaidam, Bohai Bay, TurpanHami and Yinggehai-Qiongnan basins is mainly composed 
Table 5 Activation energy of gas production from source rocks in different basins

\begin{tabular}{|c|c|c|c|}
\hline \multirow{2}{*}{ Source rocks } & \multicolumn{2}{|c|}{ Activation energy, $\mathrm{KJ} / \mathrm{mol}$} & \multirow{2}{*}{ Data source } \\
\hline & Methane & Heavy hydrocarbon & \\
\hline Jurassic coal in the Kuche Sag & 235 & 269 & Li et al, 2003 \\
\hline Jurassic mudstone in the Kuche Sag & 206 & 223 & Li et al, 2003 \\
\hline Tertiary oil shale in the Dongying Sag & 272 & 259 & Wang et al, 2003a \\
\hline Jurassic coal in the southwest Tarim Basin & 227 & 281 & Li et al, 2004 \\
\hline Jurassic mudstone in the southwest Tarim Basin & 223 & 281 & Li et al, 2004 \\
\hline Yancheng Formation kerogen in the Qiongdongnan Basin & 231 & -- & Li et al, 2005b \\
\hline Shanxi Formation coal in the Ordos Basin & 273 & -- & Mi et al, 2005 \\
\hline Coal in the Turpan-Hami Basin & 209 & 169 & $\mathrm{Xu}$ et al, 2008 \\
\hline Mudstone in the Turpan-Hami Basin & 191 & 147 & Xu et al, 2008 \\
\hline
\end{tabular}

of biogas and low-mature gas. The biogas is divided into two types according to their sources, one is from source rocks, and the other is from hydrocarbon reservoirs. The biogases derived from source rocks are classified further into primary biogas and secondary biogas. The former is generated from immature source rocks in primary burial stage, and the latter is generated from the source rocks in uplift or secondary burial stage.

The identifying parameters of shallow-buried gas are given. Choosing suitable identifying parameters combined with the analysis of accumulation conditions can distinguish the genetic types of shallow-buried gases effectively. The heavy hydrocarbon content of biogas is lower than that of low-mature gas. The former is lower than $0.5 \%$, and the latter is about $2 \%-30 \%$. The $\delta^{13} \mathrm{C}_{1}$ of biogas is less than $-55 \%$, but that of low-mature gas is about $-50 \%$ to $-42 \%$. The difference between biogas derived from source rocks and biogas derived from hydrocarbon reservoirs is mainly demonstrated in the $\delta^{13} \mathrm{C}$ of $\mathrm{CO}_{2}$. The latter is much heavier than the former. The carbon isotope of heavy hydrocarbons can be used to identify the primary biogas and secondary biogas. The heavy hydrocarbons of secondary biogas show thermal genetic characteristics and their carbon isotope of $\mathrm{C}_{2+}$ is heavier than that of the primary biogas, generally $\delta^{13} \mathrm{C}_{2}>-40 \%$.

The distribution of different types of shallow-buried gas is controlled by different factors. Primary biogas generated from source rocks is mostly distributed in Quaternary basins or modern deltas, and its accumulation is controlled by the properties of the reservoir and caprock assemblages. Secondary biogas is mainly found in a basin with secondary burial history, and the distribution is controlled by fault activity. The oil-degraded biogas is distributed near heavy oil pools, and the more the oil is biodegraded, the more biogas accumulated. The low-mature gases are widely distributed in shallow-buried reservoirs in many basins.

\section{References}

Chen Y, Qi H F and Dai J X. On some theoretical and methodological topics of biogenic gas studies. Petroleum Geology \& Experiment. 1994. 16(3): 209-219 (in Chinese)
Dai J X. Identification of different kinds of alkane gases. Science in China, Ser. B. 1992. 22(2): 185-193 (in Chinese)

Flores R M, Rice C A, Stricker G D, et al. Methanogenic pathways of coal-bed gas in the Powder River Basin, United States: The geologic factor. International Journal of Coal Geology. 2008. 76(1-2): 52-75

Galimov E M. Sources and mechanisms of formation of gaseous hydrocarbons in sedimentary rocks. Chemical Geology. 1988. 71(1-3): 77-95

Li X Q, Xiao X M, Tang Y, et al. Kinetic study of carbon isotopes in humic gas methane in the Kuqa Depression. Oil \& Gas Geology. 2004. 25(1): 21-25 (in Chinese)

Li X Q, Xiao X M, Tang Y C, et al. The origin evaluation of natural gas using carbon isotope kinetic modeling. China Petroleum Exploration. 2003. 8(4): 50-55 (in Chinese)

Li X Q, Zhang S C, Zhu G Y, et al. Types and research direction of biogenic gas in China. Natural Gas Geoscience. 2005a. 16(4): 477-484 (in Chinese)

Li X S, Xiao X M, Huang B J, et al. Hydrocarbon-generating dynamics and carbon isotope dynamics of the source rocks in Yanan Sag. Natural Gas Industry. 2005b. 25(8): 9-11 (in Chinese)

Liu W H and $\mathrm{Xu}$ Y C. Relationship between oil and gas from the bio-, thermo-catalytic transitional zone. Acta Sedimentologica Sinica. 1995. 13(2): 4-13 (in Chinese)

Liu W H and Xu Y C. Genetic indicators for natural gases. Acta Sedimentologica Sinica. 1996. 14(1): 20-28 (in Chinese)

Mi J K, Liu X H, Yang M D, et al. Discussion on the source of oil and gas using the dynamics of carbon isotope and hydrocarbon generation. Acta Sedimentologica Sinica. 2005. 23(3): 537-541 (in Chinese)

Pallasser R J. Recognising biodegradation in gas/oil accumulations through the $\delta^{13} \mathrm{C}$ compositions of gas components. Organic Geochemistry. 2000. 31(12): 1363-1373

Rice D D and Claypool G E. Generation, accumulation, and resource potential of biogenic gas. AAPG Bulletin. 1981. 65(1): 5-25

Shi Z Z. Study on biogas in Bohaiwan Basin and its surroundings. Natural Gas Industry. 2002. 22(5): 11-16 (in Chinese)

Song Y and Xu Y C. Origin and identification of natural gases. Petroleum Exploration and Development. 2005. 32(4): 24-28 (in Chinese)

Wang J B, Xiao X M, Guo R T, et al. Study of the hydrocarbon generation kinetics of source rocks from the Dongying Depression, the Bohaiwan Basin. Petroleum Geology \& Experiment. 2003a. 25(4): 403-409 (in Chinese) 
Wang W C, Liu W H and Liu Q Y. Analysis of the carbon isotopic geochemistry of the mix-sourced shallow reservoir natural gas indentification. Natural Gas Geoscience. 2003b. 14(6): 469-473 (in Chinese)

Wang W C, Liu W H and Xu Y C. The natural gas geochemistry characteristics in the Liaohe Basin. In: Annual Report of Biology and Gas Geochemistry Laboratory of Lanzhou Institute of Geology, Chinese Academy of Sciences. Lanzhou: Gansu Science and Technology Press. 1988. 30-46 (in Chinese)

Whiticar M J, Faber E and Schoell M. Biogenic methane formation in marine and freshwater environments: $\mathrm{CO}_{2}$ reduction vs. acetate fermentation-isotope evidence. Geochemical et Cosmochimica Acta. 1986. 50(5): 693-709

Xu Y C. Theory and Application of Natural Gas Genesis. Beijing: Science Press. 1994. 4-14 (in Chinese)

$\mathrm{Xu}$ Y C. The problems about the study of natural gas geochemistry. Natural Gas Geoscience. 1999. 10(3): 20-28 (in Chinese)
Xu Y C, Shen P, Liu W H, et al. A new genetic type of gas-biothermo-catalytic transitional belt gas. Science in China. 1990. (9): 975-980 (in Chinese)

Xu Y C, Wang Z Y, Wang X F, et al. Low mature gas and typical gas fields in China. Science in China, Ser. D. 2008. 38(1): 87-93 (in Chinese)

Zhang Y, Li J and Hu C Y. Reservoir formation and resource potential of biogenic-low maturity gases in China. Petroleum Exploration and Development. 2005. 32(4): 37-41 (in Chinese)

Zhu G Y, Jin Q, Zhang S C, et al. Character and genetic types of shallow gas pools in Jiyang Depression. Organic Geochemistry. 2005. 35: 1650-1663 (in Chinese)

Zhu G Y, Zhang S C, Zhao W Z, et al. Geochemical characteristics and genetic mechanisms of shallow layer gas in heavy oil areas of China. Science in China, Ser. D. 2007. 37(supplement): 80-89 (in Chinese)

(Edited by Hao Jie) 